\title{
THE CHRONOLOGY OF THE SUBOTIV SETTLEMENT
}

\author{
VICTOR I. KLOCHKO, ${ }^{1}$ NIKOLAI N. KOVALIUKH, ${ }^{2}$ VADIM V. SKRIPKIN ${ }^{2}$ and \\ INGO MOTZENBECKER ${ }^{3}$
}

\begin{abstract}
Samples collected at the Chornoliska culture site near the village of Subotiv, Cherkasy region during the 1994 1995 Ukrainian-German expedition were radiocarbon dated in Kiev. The foundation of the Subotiv settlement dates to 1300 $1200 \mathrm{cal} \mathrm{BC}$. A skeleton found in one of the buildings at this site is dated at the end of the early period (between 1120 and 1040 cal BC). In the youngest part (a small town) of the Subotiv settlement, we found the remains of a "building sacrifice"-the skeleton of a teenager. The average calibrated date for this skeleton is $834-807 \mathrm{cal} \mathrm{BC}$, whereas the timber from the rampart dates between 902-810 cal BC. Thus, the rampart was apparently built between 834-807 cal BC. Among the objects found on the site were Arzhan-type bone arrowheads. Such arrowheads, when found in Eastern Europe, are believed to indicate the military expansion of Proto-Scythian nomads. The Sargary settlement in western Kazakhstan dates to $960-820$ cal BC, the Arzhan arrow in Siberia to $960-850 \mathrm{cal} \mathrm{BC}$. We assume that the Chornogorivka complexes in eastern Eurasia date to the earlier time period (960-820) than those in western Eurasia (834-807). The time of the Chornogorivka expansion on the territory of Ukraine is therefore within the range 834 to $820 \mathrm{BC}$.
\end{abstract}

\section{INTRODUCTION}

The Chornoliska culture, discovered by Ukrainian archaeologist A. I. Terenoghkin in the 1950s1960s (Terenoghkin 1961), was spread over a vast geographical area. The area included the forest-steppe zone between the Dniester and Dnieper Rivers, and the Vorskla River basin (a tributary of the Dnieper River). This culture is contemporaneous with the monuments of the Ha A-B periods in Central Europe, the Tracian Halstatt cultures, the Luzitanian culture in Poland, and, partially, the Cimmerian period of the northern Black Sea area; this culture directly preceeds the Scythians. The culture comprises two periods dated by traditional archaeological methods: the early period (XthIXth centuries BC) and the later period (VIIIth century to the first half of the VIIth century BC) (Terenoghkin 1971).

The artifacts of the Chornoliska culture are closer in general appearance to those of Urnenfeld and Trakia Halstatt cultures than to monuments of Eastern cultures (Sroubnaia and Andronovskaia). By now $c a .100$ settlements of this culture are known, but detailed excavations were conducted only on selected sites and, in addition, covered a very small area. The most thoroughly excavated Chornoliska culture sites are located at the Tiasmyn River basin. The best-studied site is Subotiv, located in the Lower Tiasmyn area near the village of Subotiv, Cherkasy region, Ukraine. Terenoghkin excavated this site many years ago, but the work was not finished and the materials were unpublished. Some excavated materials are shown in Figures 1 and 2.

The goals of the recent joint Ukrainian-German research at Subotiv were to complete excavations on the site, investigate the stratigraphy, and collect materials for metallurgical analysis and radiocarbon dating. ${ }^{14} \mathrm{C}$ dating of this site is of great importance for both the Chornoliska culture and for determining the exact dates of the end of this culture and the appearance of the Chornogorivka-type sites- the first wave of the Eastern Proto-Scythian nomads in the northern Black Sea area. This will allow us to determine the beginning of ethnic and cultural processes resulting in formation of the Scythian culture in Eastern Europe.

\footnotetext{
${ }^{1}$ Institute of Archaeology of the National Academy of Sciences of Ukraine, 12 Heroyev Stalingrada Ave., Kiev 254655 Ukraine ${ }^{2}$ State Scientific Center of Environmental Radiogeochemistry of the National Academy of Sciences of Ukraine, 34 Palladin Ave., Kiev 142, 252680 Ukraine

${ }^{3}$ Deutsches Archäologisches Institut, Eurazien Abteilung, Postfach 330014, D-14191 Berlin, Germany
} 


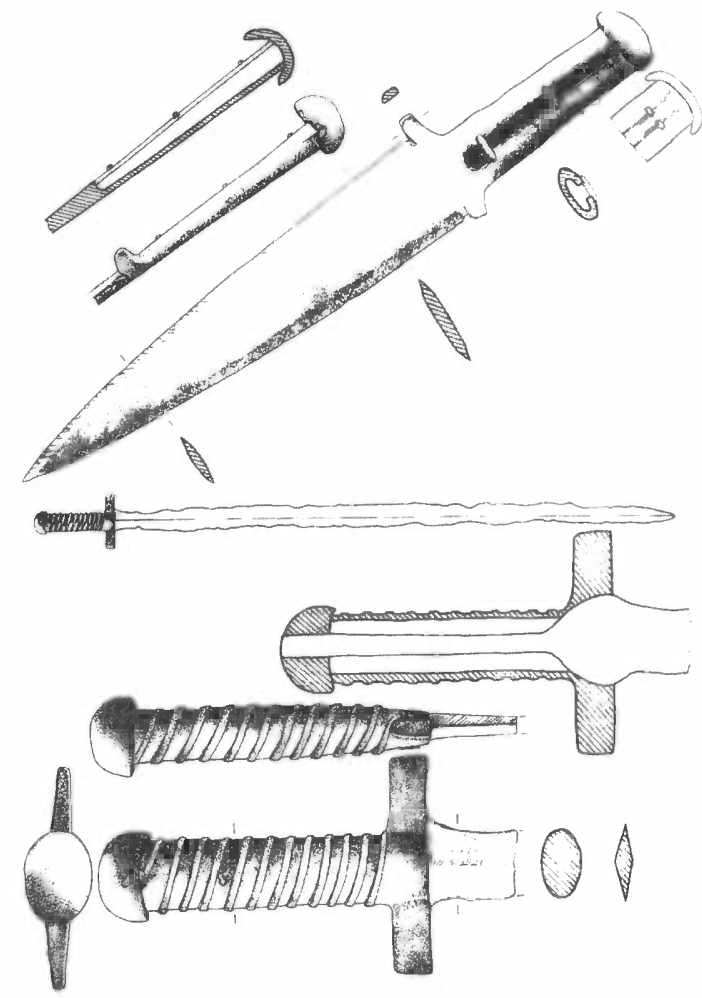

Fig. 1. Materials excavated at the Subotiv site: A) bronze dagger ("karasuk" type). B) iron sword with bronze hilt.
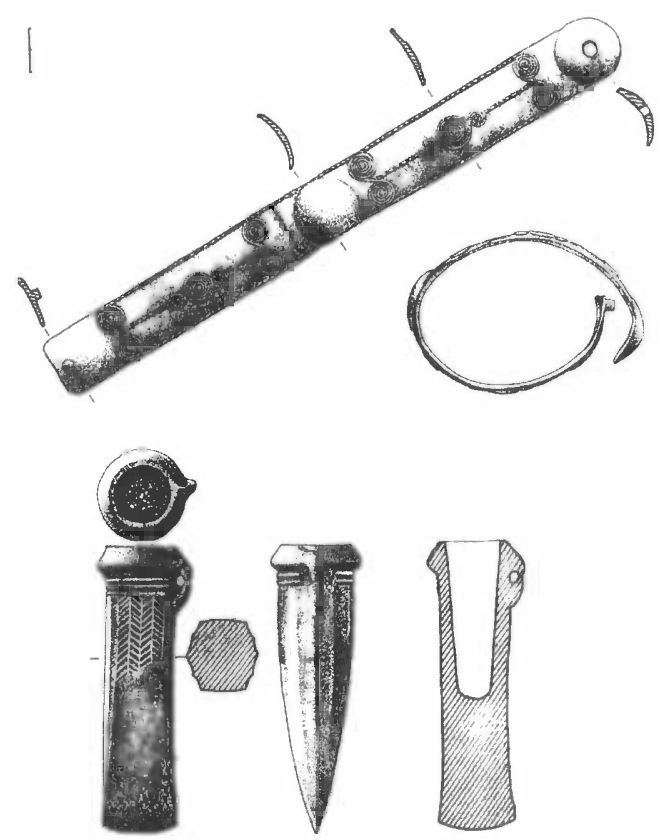

Fig. 2. Bronze bracelet and bush ax found in 1955 at Subotiv site

\section{METHODS}

The Kiev laboratory has developed a new method for lithium carbide production from organic materials. This technique allows us to obtain lithium carbide from bone collagen without preliminary extraction of the collagen. The bones are divided into small parts and after washing thoroughly with trisodiumphosphate solution, and are treated with $2 \%$ hydrofluoric acid. This acid decomposes carbonates but fixes calcium. It gives the sample a porous and solid structure, which allows easy washing and cleaning. The sample treated in this way is mixed with manganese dioxide and placed into the reactor for vacuum thermodestruction. The lithium carbide yield is $c a .95 \%$. This method performs well, especially for small samples (Skripkin and Kovalyukh 1998). The samples were measured with a Quantulus ${ }^{\mathrm{TM}} 1220$ liquid scintillation counter (LSC), using 7.3 and 0.8-mL Teflon ${ }^{\circledR}$ vials and $4 \mathrm{~g} \mathrm{~L}^{-1}$ PPO plus $0.1 \mathrm{~g} \mathrm{~L}^{-1}$ POPOP.

\section{RESULTS}

\section{Chronology of the Subotiv Site}

The main aim of the joint Ukrainian-German research at the Subotiv site was to obtain a series of ${ }^{14} \mathrm{C}$ dates. The dating material consisted mainly of animal and human bones, taken from carefully stratified layers representing all periods of the settlement (Fig. 3).

Table 1 shows the ${ }^{14} \mathrm{C}$ dates. The results were calibrated using the Groningen Radiocarbon Calibration Program (van der Plicht 1993), employing the dataset from Stuiver and Pearson (1986), and 


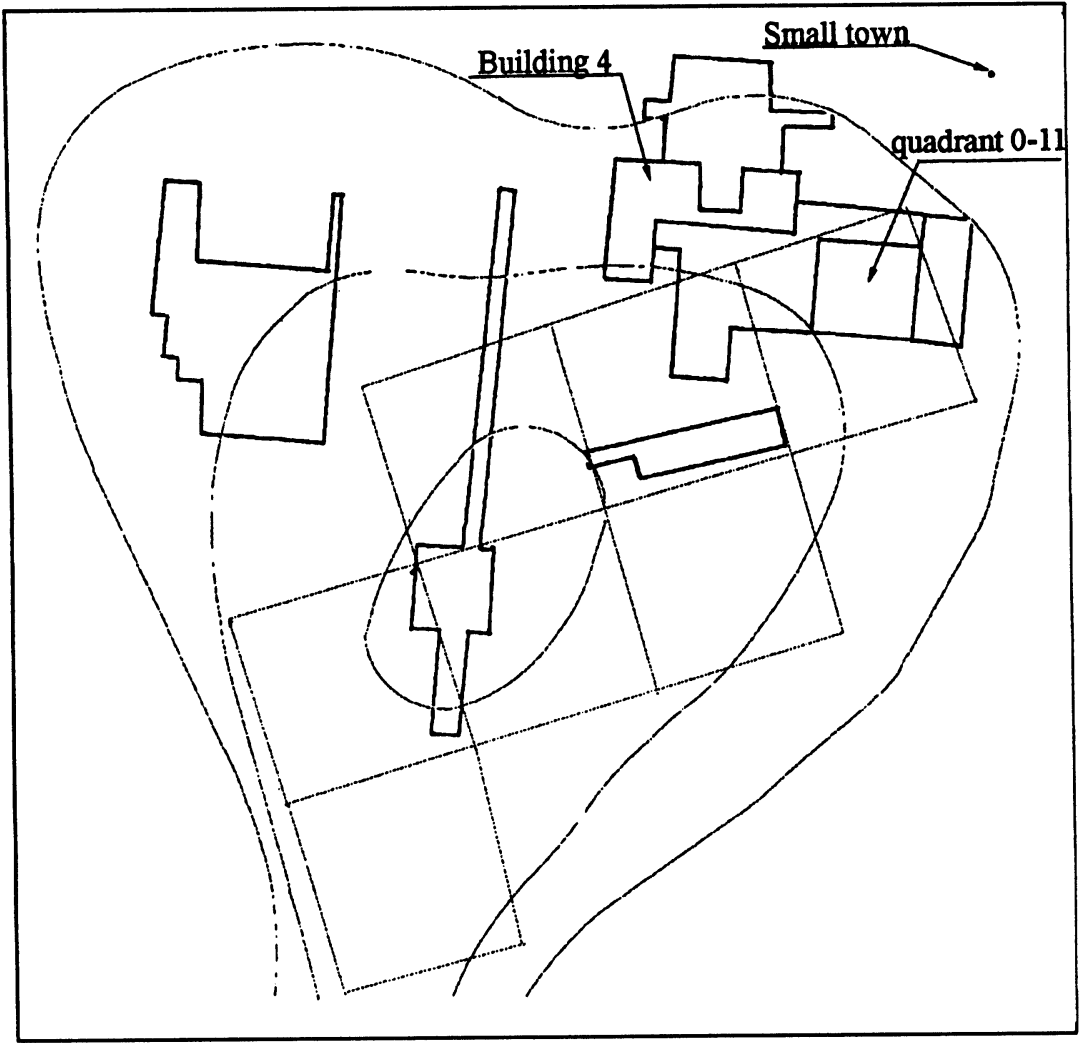

Fig. 3. Map showing the excavations at the Subotiv site

Pearson and Stuiver (1986). The earliest dates were obtained for the bottom of Building no. 4 (Ki5505,5502 and 5504). The average result for these 3 dates is $3055 \pm 35 \mathrm{BP}$. The calibrated result $(2 \sigma)$ is 1404-1254 and 1244-1210 cal BC. Taking into account the archaeological and historical information available for the Chornoliska culture, the preferable interval for the construction of Building no. 4 is $1244-1210$ cal BC.

The period when the building ceased to be used as a living quarters is estimated from the dating of a human skeleton buried inside: i.e., 1125-1028 cal BC (average date). Thus, the first horizon of the settlement is traced to the time range (1244-210)-(1125-1028) cal BC. The life activity at the "quadrant $0-11$ " excavation site is dated between 1218 and 1006 (Ki-5863), and 1032 and 900 (Ki-5864) cal BC. The youngest object of the site is the small town's rampart, built on the cultural layer of the Chornoliska period. Under the rampart, human remains from a "building sacrifice" were found. Table 2 shows the dates of the skeleton and the timber from the rampart.

As seen from Table 2, the rampart was constructed no later than 815-804 cal BC (1 o) or 825-801 cal BC $(2 \sigma)$. We believe that this date marks end of human occupation of the site. Hence, the second Chornoliska culture period of the Subotiv site can be dated to $1000-800 \mathrm{cal}$ BC. The samples from the excavations of the small town were ${ }^{14} \mathrm{C}$ dated using different fragments of the skeleton. The fragments were subjected to independent physical-chemical treatments followed by an independent measurement of the ${ }^{14} \mathrm{C}$ content in each one. We obtained a series of ${ }^{14} \mathrm{C}$ dates with an average statistical error of $19 \mathrm{yr}$. This allows minimization of the age uncertainty after calibration (Table 2). The age of some skeleton fragments differ from the average date, but within statistical scatter. 
TABLE 1. Radiocarbon Dating of the Samples from the Subotiv Site

\begin{tabular}{|c|c|c|c|c|c|}
\hline \multirow[b]{2}{*}{ No. } & \multirow[b]{2}{*}{ Sample location } & \multirow{2}{*}{$\begin{array}{l}\text { Sample } \\
\text { material }\end{array}$} & \multirow{2}{*}{$\begin{array}{l}\text { Lab no. } \\
\text { (Ki-) }\end{array}$} & \multicolumn{2}{|c|}{${ }^{14} \mathrm{C}$ age } \\
\hline & & & & BP & cal BC \\
\hline 1 & Building no. 4 & Bones & 5507 & $2910 \pm 55$ & $\begin{array}{c}1 \sigma 1198-1186 \\
1164-1143 \\
1132-1002 \\
2 \sigma 1260-1234 \\
1220-930\end{array}$ \\
\hline 2 & Debris from building no. 4 & Bones & 5506 & $2940 \pm 50$ & $\begin{array}{c}101250-1248 \\
1206-1174 \\
1170-1046 \\
2 \sigma 1304-1286 \\
1268-994\end{array}$ \\
\hline 3 & Debris from building no.4 & Bones & 5501 & $2950 \pm 45$ & $\begin{array}{r}101256-1240 \\
1212-1113 \\
1096-1064 \\
201296-1290 \\
1266-1006\end{array}$ \\
\hline 4 & Debris from building no. 4 & Bones & 5508 & $3010 \pm 50$ & $\begin{array}{r}1 \sigma 1366-1360 \\
1312-1164 \\
1144-1130 \\
2 \sigma 1396-1114 \\
1094-1070\end{array}$ \\
\hline 5 & Debris from building no. 4 & Bones & 5503 & $2980 \pm 60$ & $\begin{array}{r}101306-1284 \\
1268-1115 \\
1090-1076 \\
201386-1342 \\
1320-1014\end{array}$ \\
\hline 6 & Hole no. 1, building no. 4 & Coal & 5504 & $3030 \pm 60$ & $\begin{array}{r}101386-1342 \\
1322-1202 \\
1182-1166 \\
1140-1134 \\
201414-1114 \\
1096-1070\end{array}$ \\
\hline 7 & Bottom, building no. 4 & Coal & 5502 & $3040 \pm 50$ & $\begin{array}{r}1 \sigma 1388-1340 \\
1324-1254 \\
1242-1210 \\
2 \sigma 1406-1158 \\
1148-1126\end{array}$ \\
\hline 8 & Bottom, building no. 4 & Coal & 5505 & $3100 \pm 40$ & $\begin{array}{r}1 \sigma 1410-1366 \\
1358-1312 \\
2 \sigma 1430-1262\end{array}$ \\
\hline 9 & Quadrant 0-11, sample no. $4 / 1$ & Bones & 5863 & $2935 \pm 40$ & $\begin{array}{r}1 \sigma 1202-1184 \\
1166-1141 \\
1134-1044 \\
2 \sigma 1260-1236 \\
1218-1006\end{array}$ \\
\hline 10 & Quadrant $0-11$, sample no. $3 / 1$ & Bones & 5859 & $2930 \pm 40$ & $\begin{array}{r}1 \sigma 1198-1186 \\
1166-1142 \\
1132-1036 \\
201258-1236 \\
1216-1004\end{array}$ \\
\hline
\end{tabular}


TABLE 1. Radiocarbon Dating of the Samples from the Subotiv Site (Continued)

\begin{tabular}{|c|c|c|c|c|c|}
\hline \multirow[b]{2}{*}{ No. } & \multirow[b]{2}{*}{ Sample location } & \multirow{2}{*}{$\begin{array}{l}\text { Sample } \\
\text { material }\end{array}$} & \multirow{2}{*}{$\begin{array}{l}\text { Lab no. } \\
\text { (Ki-) }\end{array}$} & \multicolumn{2}{|c|}{${ }^{14} \mathrm{C}$ age } \\
\hline & & & & BP & cal BC \\
\hline 11 & $\begin{array}{l}\text { Quadrant } 0-11 \\
\text { Northwestern square, eastern wall } \\
\text { Sample no. } 3 / 2\end{array}$ & Coal & 5858 & $2910 \pm 35$ & $\begin{array}{c}1 \sigma 1124-1020 \\
2 \sigma 1252-1246 \\
1206-994\end{array}$ \\
\hline 12 & $\begin{array}{l}\text { Quadrant } 0-11 \\
\text { Sample no. } 4 / 2\end{array}$ & Bones & 5862 & $2890 \pm 30$ & $\begin{array}{c}1 \sigma 1115-1092 \\
1074-1006 \\
2 \sigma 1160-1147 \\
1128-986 \\
960-938\end{array}$ \\
\hline 13 & $\begin{array}{l}\text { Quadrant 0-11 } \\
\text { Sample no. 4/1A }\end{array}$ & Bones & 5869 & $2860 \pm 30$ & $\begin{array}{c}1 \sigma 1044-982 \\
966-932 \\
2 \sigma 1116-1090 \\
1078-924\end{array}$ \\
\hline 14 & $\begin{array}{l}\text { Quadrant } 0-11 \\
\text { Southeastern square } \\
\text { Sample no. } 4 / 3\end{array}$ & Bones & 5861 & $2875 \pm 40$ & $\begin{array}{c}1 \sigma 1116-1090 \\
1078-990 \\
954-942 \\
201160-1146 \\
1128-918\end{array}$ \\
\hline 15 & $\begin{array}{l}\text { Quadrant } 0-11 \\
\text { Southeastern square } \\
\text { Sample no. 4/3A }\end{array}$ & Bones & 5867 & $2875 \pm 40$ & $\begin{array}{c}1 \sigma 1116-1090 \\
1078-990 \\
954-942 \\
201160-1146 \\
1128-918\end{array}$ \\
\hline 16 & $\begin{array}{l}\text { Quadrant } 0-11 \\
\text { Sample no. 3/1A }\end{array}$ & Bones & 5865 & $2850 \pm 35$ & $\begin{array}{c}1 \sigma 1030-974 \\
972-930 \\
2 \sigma 1116-1090 \\
1078-912\end{array}$ \\
\hline 17 & $\begin{array}{l}\text { Quadrant } 0-11 \\
\text { Southwestern square } \\
\text { Sample no. } 7\end{array}$ & Bones & 5860 & $2845 \pm 35$ & $\begin{array}{c}1 \sigma 1020-928 \\
2 \sigma 1115-1092 \\
1076-908\end{array}$ \\
\hline 18 & $\begin{array}{l}\text { Quadrant } 0-11 \\
\text { Sample no. } 3 / 1 \mathrm{H}\end{array}$ & Bones & 5866 & $2870 \pm 50$ & $\begin{array}{c}1 \sigma 1116-1090 \\
1080-984 \\
962-934 \\
2 \sigma 1202-1182 \\
1168-1140 \\
1136-906\end{array}$ \\
\hline 19 & $\begin{array}{l}\text { Quadrant 0-11 } \\
\text { Northwestern square, eastern wall } \\
\text { Sample no. 3/2/A }\end{array}$ & Bones & 5864 & $2820 \pm 30$ & $\begin{array}{r}1 \sigma 992-950 \\
948-922 \\
2 \sigma 1032-900\end{array}$ \\
\hline 20 & $\begin{array}{l}\text { Quadrant 0-11 } \\
\text { Sample no. 4/2A }\end{array}$ & Bones & 5868 & $2830 \pm 40$ & $\begin{array}{c}1 \sigma 1008-916 \\
2 \sigma 1115-1092 \\
1076-898 \\
874-852\end{array}$ \\
\hline 21 & $\begin{array}{l}\text { Small town timber from the rampart } \\
\text { (average date) }\end{array}$ & Timber & $5368-5370$ & $2708 \pm 35$ & $\begin{array}{r}1 \sigma 898-876 \\
850-814 \\
2 \sigma 906-808\end{array}$ \\
\hline 22 & $\begin{array}{l}\text { Small town. Human skeleton from under the } \\
\text { rampart (average date) }\end{array}$ & Bones & $5359-5367$ & $2680 \pm 17$ & $\begin{array}{l}1 \sigma 824-810 \\
2 \sigma 834-807\end{array}$ \\
\hline 23 & Settlement of Sargary & Timber & Le-1183 & $2700 \pm 60$ & $\begin{array}{r}1 \sigma 900-868 \\
860-808 \\
2 \sigma 986-960 \\
938-792\end{array}$ \\
\hline
\end{tabular}


TABLE 2. Dating Results for Skeleton Fragments Found Under the Rampart of Subotiv Village, Cherkasy Region

\begin{tabular}{|c|c|c|c|c|c|c|c|}
\hline $\begin{array}{l}\text { Sample } \\
\text { no. }\end{array}$ & $\begin{array}{l}\text { Lab no. } \\
\text { (Ki-) }\end{array}$ & $\begin{array}{l}{ }^{14} \mathrm{C} \text { age } \\
\text { (yr BP) }\end{array}$ & $\begin{array}{l}\text { Calibrated } \\
\text { age }(\mathrm{BC})\end{array}$ & $\begin{array}{l}\text { Sample } \\
\text { no. }\end{array}$ & $\begin{array}{l}\text { Lab no. } \\
\text { (Ki-) }\end{array}$ & $\begin{array}{l}{ }^{14} \mathrm{C} \text { age } \\
\text { (yr BP) }\end{array}$ & $\begin{array}{l}\text { Calibrated } \\
\text { age (BC) }\end{array}$ \\
\hline 1 & 5359 & $2610 \pm 40$ & $\begin{array}{r}1 \sigma 812-776 \\
2 \sigma 836-760 \\
674-664 \\
630-592 \\
580-544\end{array}$ & 6 & 5364 & $2710 \pm 45$ & $\begin{array}{r}1 \sigma 900-872 \\
854-812 \\
2 \sigma 922-802\end{array}$ \\
\hline 2 & 5360 & $2640 \pm 35$ & $\begin{array}{l}1 \sigma 820-796 \\
2 \sigma 842-776\end{array}$ & 7 & 5365 & $2600 \pm 40$ & $\begin{array}{r}1 \sigma 810-770 \\
2 \sigma 828-760 \\
678-658 \\
634-550\end{array}$ \\
\hline 3 & 5361 & $2700 \pm 40$ & $\begin{array}{r}1 \sigma 896-876 \\
850-808 \\
2 \sigma 908-804\end{array}$ & 8 & 5366 & $2680 \pm 35$ & $\begin{array}{r}1 \sigma 842-802 \\
2 \sigma 900-866 \\
860-800\end{array}$ \\
\hline 4 & 5362 & $2730 \pm 40$ & $\begin{array}{l}1 \sigma 900-830 \\
2 \sigma 930-806\end{array}$ & 9 & 5367 & $2655 \pm 30$ & $\begin{array}{l}1 \sigma 822-802 \\
2 \sigma 844-732\end{array}$ \\
\hline 5 & 5363 & $2590 \pm 45$ & $\begin{array}{r}1 \sigma 814-762 \\
626-598 \\
568-566 \\
2 \sigma 824-756 \\
686-540\end{array}$ & Average & late & $2657 \pm 19$ & $\begin{array}{l}1 \sigma 815-804 \\
2 \sigma 825-801\end{array}$ \\
\hline
\end{tabular}

\section{DisCUSSION AND CONCLUSION}

Among the Eurasian monuments contemporaneous with the second Chornoliska culture horizon of the Subotiv site dated by the ${ }^{14} \mathrm{C}$ method, the Tuva Arzhan burial mound is of particular interest. The bone arrowheads from this burial mound are similar to the rhomboidal arrows of the Subotiv site. We relate the appearance of those arrows in Subotiv with the termination of human activities at the site. The latest ${ }^{14} \mathrm{C}$ date of the burial mound is $810 \mathrm{cal} \mathrm{BC} \mathrm{(Marsadolov} \mathrm{et} \mathrm{al.} \mathrm{1996;} \mathrm{Zaitseva} \mathrm{et} \mathrm{al.}$ 1996). By correlating the dendrochronological and ${ }^{14} \mathrm{C}$ dates of the burial mound, we obtained a date of $800 \mathrm{BC}$ (Zaitseva et al. 1996). ${ }^{14} \mathrm{C}$ dates of the Arzhan site are contemporaneous with the those of the termination of the Subotiv site. The ${ }^{14} \mathrm{C}$ date for Building 5 (mud-hut) in the Sargary settlement in Western Kazakhstan, where arrowheads of the Arzhan type were found, yields $2700 \pm 60 \mathrm{BP}$ (Le1183). The calibrated date is 938-792 cal BC (Avanesova 1991). Both archaeological materials (arrows of the Arzhan type) and ${ }^{14} \mathrm{C}$ dates allow us to view these three monuments within the framework of one historic hypothesis concerning the Western expansion of "proto-Scythians" (Klochko and Murzin 1987a,b, 1989). Chochorowski proposed to date this event-which he called a "Cimmerian expansion to the territory of Central Europe"-between 950 and 880 BC (Chochorowski 1995). In terms of our recent dates, we believe that this expansion of Eastern nomads-which caused the emergence of the Chornogorivka culture in the Ukraine territory (Dubovskaya 1993)-occurred no later than $820-800 \mathrm{BC}$. 


\section{REFERENCES}

Avanesova, N. A. 1991 Culture of Shepherd Tribes in the Bronze Age in the Asian Part of the USSR (Based on Metal Wares). Tashkent: 200 p. (in Russian).

Chochorowski, J. 1995 Dating of the Cimmerian Horizon in Central Europe and Late Bronze Age Prahistorychne, Vol. 4. Katovice: 267-28 (in Polish).

Dubovskaya, O. P. 1993 Questions of composition of the Chornogorivska implement complex. Archeologicheski Almanac 2. Donetsk: 137-160 (in Russian).

Klochko, V. I. and Murzin, V. Y. 1987a About Interference of the Local and Introduced Elements of the Scythian Culture. Scythians of the Northern Black Sea Area. Kiev, Naukova Dumka: 12-19 (in Russian).

1987b About dating of the Chornogorivska Novocherkask sites. Cimmerians and Scythians. Proceedings of the all-Union workshop devoted to the memory of Dr. A. I. Ternozhkin. Kirovograd: 73-75 (in Russian).

1989 About the Chronology of Antiquities of the Chornogorivska Novocherkask. Problems of Archaeology of the Dnieper Area. Dnipropetrovsk, Dnipropetrovskiy University: 61-71 (in Russian).

Marsadolov, L. S., Zaitseva G. I., Sementsov, A. A. and Lebedeva L. M. 1996 Possibilities of radiocarbon dating to relate the variable scale of large burial mounds of the Saiano-Altai to the calendar. Radiocarbon and Archaeology (St. Petersburg): 1: 24-32 (in Russian).
Pearson, G. W. and Stuiver, M. 1986 High-precision calibration of the radiocarbon time scale, 500-2500 BC. In Stuiver, $\mathbf{M}$. and $\mathrm{Kra}, \mathbf{R}$., eds., Calibration Issue. $\mathbf{R} a$ diocarbon 28(2B): 839-862.

Skripkin, V. and Kovalyukh, N. 1998 Recent developments in the procedures used at the SSCER Laboratory for the routine preparation of lithium carbide. $R a$ diocarbon, this issue.

Stuiver, M. and Pearson. G. W. 1986 High-precision calibration of the radiocarbon time scale, AD 1950-500 BC. In Stuiver, M. and Kra, R., eds., Calibration Issue. Radiocarbon 28(2B): 805-838.

van der Plicht, J. 1993 The Groningen radiocarbon calibration program. In Stuiver, M., Long, A. and Kra, R. S., eds., Calibration 1993. Radiocarbon 35(1): 231237.

Terenoghkin, A. I. 1961 Pre-Scythian Period on the Right Bank of the Dnieper. Kiev, Naukova Dumka: 246 p. (in Russian).

1971 The Cimmerians. Kiev, Naukova Dumka: 220 p. (in Russian).

Zaitseva, G. I., Vasiliev, S. S., Marsadov, Z. S. et al. 1996 Employment of the mathematical statistics method for correlation of dendrochronological and radiocarbon data (basing on Saiano-Altai elite burial mounds' materials). Radiocarbon and Archeology (St. Petersburg) 1: 33-38 (in Russian). 